\title{
TOLERANCE OF DRY BEAN CULTIVARS TO SAFLUFENACIL
}

\author{
Tolerância de cultivares de feijão ao herbicida saflufenacil
}

\author{
Francielli Diesel $^{1}$, Michelangelo Muzell Trezzi ${ }^{2}$, Paulo Henrique Oliveira ${ }^{2}$, \\ Elouize Xavier², Daiana Pazuch ${ }^{2}$, Fortunato Pagnoncelli Junior ${ }^{2}$
}

\begin{abstract}
The herbicide saflufenacil is a Protox inhibitor, with differential translocation mode in comparison to other herbicides with the same mechanism of action. Selectivity, efficacy and safety to the environment are important characteristics for practical application of a herbicide in agriculture. The aim of this study was to determine the tolerance of ten dry bean cultivars to saflufenacil, applied on preemergence. The experiment was conducted in split plot randomized blocks design with ten dry bean cultivars (IAPAR 81; IPR Tiziu, IPR Corujinha; BRS Estilo; BRS Talismã; BRS Esplendor; BRS Campeiro; BRS Radiante, BRS Vereda and Jalo Precoce) allocated in plots and saflufenacil concentrations (0, 14.7 and $\left.29.4 \mathrm{~g} \mathrm{ha}^{-1}\right)$ in subplots. Evaluations were performed at 21 and 28 days after application (DAA) and plant height at 28 and 35 DAA. At physiological maturity were evaluated plant height, first pod height, number of pods per plant, 400 grains weight and dry beans grain yield. The cultivar Talismã showed low sensitivity to the herbicide and the cultivar Jalo Precoce high sensitivity to the herbicide, considering all variables analyzed.
\end{abstract}

Index terms: Selectivity, Protox inhibitor, Phaseolus vulgaris.

\begin{abstract}
RESUMO
O herbicida saflufenacil é inibidor da Protox, com modo de translocação diferenciado em relação a outros herbicidas pertencentes ao mesmo mecanismo de ação. Seletividade, eficácia e segurança ao ambiente são características importantes para aplicabilidade prática de um herbicida na agricultura. O objetivo deste estudo foi determinar a tolerância de dez cultivares de feijão ao saflufenacil, aplicado em condições de pré-emergência. O experimento foi realizado em delineamento experimental de blocos ao acaso com parcelas subdivididas com dez cultivares de feijão (IAPAR 81; IPR Tiziu; IPR Corujinha; BRS Estilo; BRS Talismã; BRS Esplendor; BRS Campeiro; BRS Radiante; BRS Vereda e Jalo precoce) alocadas nas parcelas e concentrações de saflufenacil $\left(0 ; 14,7\right.$ e 29,4 $\left.\mathrm{g} \mathrm{ha}^{-1}\right)$ nas subparcelas. Foram realizadas avaliações de estande aos 21 e 28 dias após aplicação (DAA) e estatura de plantas aos 28 e 35 DAA. Na maturação fisiológica avaliou-se estatura da planta, altura inserção da primeira vagem, número de vagens por planta, peso de 400 grãos e rendimento de grãos de feijão. A cultivar Talismã apresentou baixa sensibilidade ao herbicida e a cultivar Jalo Precoce elevada sensibilidade ao herbicida, considerando-se todas as variáveis analisadas.
\end{abstract}

Termos para indexação: Seletividade, inibidor da Protox, Phaseolus vulgaris.

\section{INTRODUCTION}

Brazil is the largest world producer of dry beans, with acreage in the crop year 2010/11 estimated at 3.9 million ha and total yield of 3.8 million tons (Barbosa; Gonzaga, 2012). The national average yield per hectare is projected to $873 \mathrm{~kg} \mathrm{ha}^{-1}$, which is considered low compared to other producer countries due to the genetic potential of currently available cultivars. The crop has a large number of genotypes, with different characteristics, grouped in various trade groups (Borém; Carneiro, 2006).

Among the annual crops grown in Brazil, the dry bean crop is the one with the greatest percentage loss to weed interference. The interference with weeds throughout the cycle can reduce grain yield 67 to $80 \%$ (Kozlowski et al., 2002; Salgado et al., 2007).
Chemical control of weeds has been the most used method in the bean crop due to greater convenience and high efficacy (Ferreira et al., 2006). Currently in Brazil there are few herbicides registered for use on dry beans. Among the desirable features of herbicides for use in the crop are good selectivity for cultivated species, favorable toxicological safety properties and environmentally friend and residual activity in the soil enough for weed control during the critical period of weed competition with the crop (Soltani, Bowley; Sikkema, 2005). Herbicide selectivity is the capacity to control weeds that are infesting the crop without reducing the yield and quality of the final product. There are herbicides that affect crop productivity without visually detectable effects and other that can cause strong injuries with no influence on final yield (Velini et al., 2000).

\footnotetext{
${ }^{1}$ Universidade Tecnológica Federal do Paraná/ UTFPR - Campus Pato Branco - Via do Conhecimento - km 01 - Cx. P. 571 - $85503-390$ - Pato Branco PR - Brasil - francielli diesel@hotmail.com

2Universidade Tecnológica Federal do Paraná/UTFPR - Pato Branco - PR - Brasil

Received in february 6, 2014 and approved in april 19, 2014
}

Ciênc. Agrotec., Lavras, v.38, n.4, p.352-360, jul./ago., 2014 
Saflufenacil is a herbicide registered recently in Brazil. It belongs to the chemical group pyrimidinedione and its mechanism of action is the inhibition of the PROTOX. This herbicide can be absorbed by the roots and leaves of the plants. Unlike other PROTOX inhibitor herbicides, which have limited translocation in phloem, saflufenacil has acropetal and basipetal translocation (Grossmann et al., 2011).

Saflufenacil is applied at relatively low doses and has low environmental, toxicological and ecotoxicological impacts by presenting minimal residual effect to cultivated species in sucession, common feature of herbicides with low residual in the soil (Soltani, Shropshire; Sikkema, 2010). This herbicide is recommended for weed desiccation prior to crop seeding, due to its broad weed species spectrum control, especially of dicots. It has shown rapid control of dicots species, including lambsquarters (Chenopodium album), common ragweed (Ambrosia artemisiifolia), sunflower (Helianthus annuus), horseweed (Conyza canadensis), morning glory (Ipomoea spp.), Commelina benghalensis, Crotalaria spectabilis, Crotalaria ochroleuca, Luffa aegyptiana, Merremia cissoides, Mucuna aterrima, Ricinus communis and various species of Amaranthus (Geier; Stahlman; Charvat, 2009; Monquero; Dalla Costa; Krolikowski, 2011; Martins et al., 2012; Inoue et al., 2012).

Saflufenacil applied for desiccation of weeds in pre-sowing must be selective for the species in sequence. Saflufenacil (50 and $100 \mathrm{~g} \mathrm{ha}^{-1}$ ) applied preemergence was selective for barley, oats and wheat, but the same doses in post-emergence were selective only for oats (Sikkema, Shropshire; Soltani, 2008; Knezevic et al., 2010). Saflufenacil (doses up to $100 \mathrm{~g} \mathrm{ha}^{-1}$ ) applied preemergence was selective to corn crops but not in postemergence (Soltani et al., 2009). Soltani et al. (2010) detected low selectivity of saflufenacil (100 and $200 \mathrm{~g}$ $\mathrm{ha}^{-1}$ ) applied preemergence on the following legumes: Vigna angularis L. "Eramo", Phaseolus vulgaris L. "Etna", Phaseolus lunatus L. "Kingston", Lathyrus odoratus L. 'Durango', Phaseolus vulgaris L. 'Matador', Glycine max L., Phaseolus vulgaris L. "OAC Rex".

This study evaluated the tolerance of ten dry bean cultivars to saflufenacil applied preemergence conditions of the crop, in clayey soil.

\section{MATERIAL AND METHODS}

The field experiment was conducted from January to June 2012, in the experimental area of the Federal Technological University (UTFPR), Campus Pato Branco $\left(26^{\circ} 07^{\prime} \mathrm{S}\right.$ and $\left.52^{\circ} 41^{\prime} \mathrm{W}\right)$. The experiment was established in soil classified as Oxisol (EMBRAPA, 2006), whose characteristics are presented in table 1.

We used a split plot, randomized complete blocks design, with ten bean cultivars allocated in the plots, whose identification and main characteristics are listed in table 2 , and saflufenacil concentrations $\left(0 ; 14.7\right.$ and $\left.29.4 \mathrm{~g} \mathrm{ha}^{-1}\right)$ were applied in the subplots.

The plots were $15 \mathrm{~m}$ long $\mathrm{x} 1.8 \mathrm{~m}$ wide and subplots were $5 \mathrm{~m}$ long $\times 1.8 \mathrm{~m}$ wide. The working area of each subplot had $4 \mathrm{~m}$ long x $0.9 \mathrm{~m}$ wide. We applied a seeding rate of 31 seeds $\mathrm{m}^{2}, 0.45$ row spacing and $3 \mathrm{~cm}$ sowing depth. Saflufenacil was sprayed on the soil after sowing, in preemergence condition of the cultivars, with a $\mathrm{CO}_{2}$ pressurized backpack sprayer, maintained at constant pressure and with fan type nozzles 110.02, apart from each other at $0.5 \mathrm{~m}$ in bar with $1.5 \mathrm{~m}$ wide, totaling a volume of solution sprayed of $200 \mathrm{~L} \mathrm{ha}^{-1}$. The conditions at the time of application were: air temperature between $25-28^{\circ} \mathrm{C}$; relative humidity between 65 and $70 \%$, maximum wind speed of $1.1 \mathrm{~m} \mathrm{~s}^{-1}$.

Plant stand evaluations was done at 21 and 28 days after application (DAA) and plant height evaluations at 28 and 35 DAA. When the crop reached physiological maturity, it was evaluated in ten randomly selected plants in the working area of each subplot, plant height, first pod height, number of pods per plant and number of seeds per pod. To determine the stand, it was counted the number of plants in $5 \mathrm{~m}$ length in the two central rows of each subplot. The height was determined in the plants within a meter of row marked in the working area of each subplot with a millimeter ruler, measuring the distance between the basis and the last leaf of the plant. The grain yield was obtained by tracking and weighing of grains throughout the working area, being corrected to $13 \%$ moisture.

Data were subjected to analysis of variance by the F-test and means were compared by a Tukey's test ( $\mathrm{p}$ $<0.05$ ), with the aid of WINSTAT (Machado; Conceição, 2005). Graphs were made with the help of the program SigmaPlot 10.0.

\section{RESULTS AND DISCUSSION}

The analyses of variance for all variables identified significant interaction between cultivars $\mathrm{x}$ doses at $5 \%$ level of significance, except for number of grains per pod, in which there was no significance of any factor or interaction.

The plant stand of all bean cultivars was reduced by the preemergence application of saflufenacil. The controls of the cultivars Corujinha, Tiziu and IAPAR 81 showed the largest plant stand compared with other cultivars controls, in both periods (Figures 1 A and B). Regarding the dose of 14.7 
$\mathrm{g} \mathrm{ha}^{-1}$, the cultivar Talismã showed the highest tolerance to soil saflufenacil in the evaluated periods, totaling $18 \%$ reduction at 28 DAA(Figure 1B). The cultivar Jalo Precoce had greater sensitivity to the herbicide with significant reduction of $86.6 \%$ of the plant stand compared with the control (Figure 1B).

In relation to the dose of $29.4 \mathrm{~g} \mathrm{ha}^{-1}$, the cultivar Talismã had the lower loss of stand in relation to other cultivars in the evaluated periods, i.e., it showed lower sensitivity in the presence of saflufenacil in the soil, with $47.8 \%$ reduction of the plant stand at 28 DAA (Figure 1B). The cultivar Jalo Precoce was very sensitive to saflufenacil in all periods, with significant reduction in plant stand, 99.6 and $99.8 \%$ at 21 and 28 DAA respectively (Figures $1 \mathrm{~A}$ and B).

The comparison of doses within each cultivar reveals that the cultivar Talismã was the only one which
$14.7 \mathrm{~g} \mathrm{ha}^{-1}$ saflufenacil did not reduce the plant stand in relation to the control without herbicide application, showing that it presented lower saflufenacil sensitivity to the presence of saflufenacil in the soil. The other cultivars showed significant loss of plant stand with increasing doses of saflufenacil.

In respect of height, controls showed no difference in any of the periods (Figures $2 \mathrm{~A}$ and B). With the use of $14.7 \mathrm{~g} \mathrm{ha}^{-1}$ saflufenacil (Figure 2), the group of cultivars composed of Corujinha, Tiziu, Vereda, IAPAR 81, Talismã and Campeiro stood by the low reduction in height. With the highest dose of saflufenacil, the cultivar Talismã showed the lowest sensitivity, in the three periods, with a decrease of only 18.8 and $15.8 \%$ compared to the control at 28 and 35 DAA, respectively (Figure $2 \mathrm{~B}$ ).

Table 1 - Particle size distribution and chemical attributes of the oxisol. UTFPR, Campus Pato Branco, 2012.

\begin{tabular}{cccc}
\hline \multicolumn{2}{c}{ Particle size distribution } & \multicolumn{2}{c}{ Chemical attributes } \\
\hline Component & $\%$ & Component & Value/ Measurement Unit \\
\hline Clay & 55.7 & $\mathrm{MO}^{* 1}$ & $49.50 \mathrm{~g} \mathrm{dm}^{-3}$ \\
Sand & 3 & $\mathrm{P}_{2} \mathrm{O}_{5}{ }^{* 2}$ & $14.32 \mathrm{mg} \mathrm{dm}^{-3}$ \\
Silt & 41.3 & $\mathrm{~K}_{2} \mathrm{O}^{* 3}$ & $0.70 \mathrm{cmol}_{\mathrm{c} \mathrm{dm}}{ }^{-3}$ \\
& & $\mathrm{CTC}^{* 4}$ & $17.63 \mathrm{cmol}_{\mathrm{c}} \mathrm{dm}^{-3}$ \\
& $\mathrm{pH}^{* 5}$ & 5.6 \\
& $\mathrm{H}+\mathrm{Al}^{* 6}$ & $5.35 \mathrm{cmol}_{\mathrm{c}} \mathrm{dm}^{-3}$ \\
\hline
\end{tabular}

${ }^{* 1}$ Organic matter; ${ }^{* 2}$ Phosphorus; ${ }^{* 3}$ Potassium; ${ }^{* 4}$ Cation exchange capacity $;{ }^{* 5}$ Soil $\mathrm{pH} ;{ }^{* 6}$ Exchangeable acidity

Table 2 - Characteristics of bean cultivars used in the experiment of tolerance to saflufenacil - UTFPR, Pato Branco/2012.

\begin{tabular}{lcccccc}
\hline \multicolumn{1}{c}{ Cultivar } & Group & Cycle $^{1}$ & Plant size & Growth habit & $\begin{array}{c}\text { 100 grain } \\
\text { weight (g) }\end{array}$ & $\begin{array}{c}\text { Adaptation to mechanical } \\
\text { harvesting }\end{array}$ \\
\hline IPR Corujinha & Pintado & Normal & Erect & Indeterminate (type II) & 22 & Yes \\
BRS Esplendor & Black & Normal & Erect & Indeterminate (type II) & 22 & Yes \\
BRS Jalo precoce & Special & Normal & Semi-erect & Indeterminate (type II) & 35 & No \\
BRS Radiante & Special & Normal & Semi-erect & Determinate (type I) & 44 & No \\
IPR Tiziu & Black & Normal & Erect & Indeterminate (type II) & 20 & Yes \\
BRS Estilo & Carioca & Normal & Erect & Indeterminate (type II) & 26 & Yes \\
BRS Vereda & Special & Normal & Semi-erect & Indeterminate (type II) & 26 & No \\
IPR IAPAR 81 & Carioca & Normal & Erect & Indeterminate (type II) & 25 & Yes \\
BRSMG Talismã & Carioca & Normal & Prostrate & Indeterminate (type III) & 26 & No \\
BRS Campeiro & Black & Semi-early & Erect & Indeterminate (type II) & 25 & Yes
\end{tabular}

${ }^{1}$ Cycle: early ( $<75$ days); semi-early ( $75-85$ days); normal ( $85-95$ days); late $\left(>95\right.$ days); ${ }^{2}$ Dry bean cultivar adaption to conventional mechanical harvester, dependending to heigh of the first pod.

Source: (Barbosa; Gonzaga, 2012). 

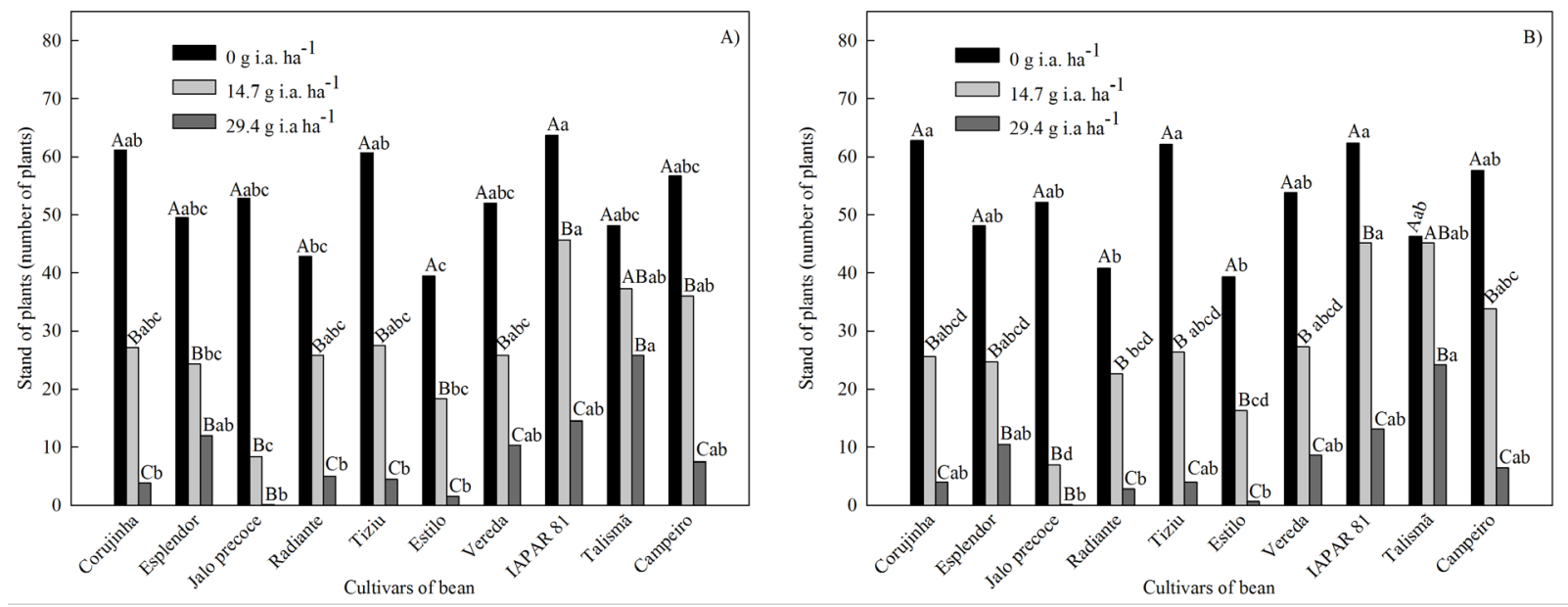

Figure 1 - Stands of plants at 21 (A) and 28 (B) DAA of ten bean cultivars in the absence of the herbicide and in response to two doses of saflufenacil. UTFPR, Pato Branco, 2012. Means values followed by the same lower case indicate no difference between cultivars, within each dose, by the Tukey test $(\mathrm{P}<0.05)((21$ DAA D.M.S=19.8; CV=24.9) (28 DAA D.M.S=21.05; $C V=27)$ ). Means values followed by the same capital letter mean no difference between doses within each cultivar, using the Tukey test $(\mathrm{P}<0.05)((21$ DAA D.M.S=14.5; $\mathrm{CV}=24.9)(28$ DAA D.M.S=15.3; $\mathrm{CV}=27))$.
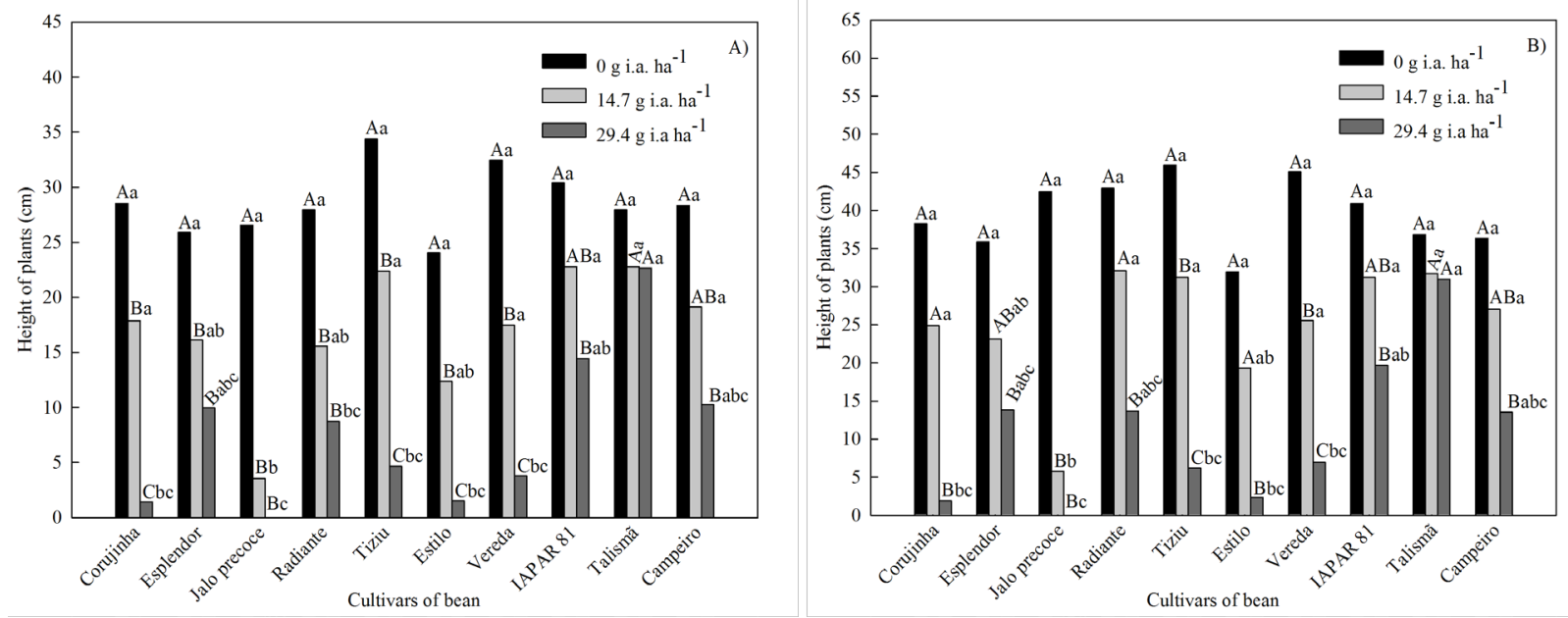

Figure 2 - Height of plants at 28 (A) and 35 DAA (B) of ten bean cultivars in response to saflufenacil concentrations. UTFPR, Pato Branco, 2012. Means values followed by the same lower case indicate no difference between cultivars, within each dose, by the Tukey test $(\mathrm{P}<0.05)((28$ DAA D.M.S=13.05; $\mathrm{CV}=27.2)$ (35 DAA D.M.S=18.8; $\mathrm{CV}=27.6))$. Means values followed by the same capital letter mean no difference between doses within each cultivar, using the Tukey test $(\mathrm{P}<0.05)((28$ DAA D.M.S=9.5; $\mathrm{CV}=27.2$ ) (35 DAA D.M.S=18.8; CV=27.6)).

The evaluation performed at $28 \mathrm{DAA}$, the height of bean plants was negatively influenced by the presence of $14.7 \mathrm{~g} \mathrm{ha}^{-1}$ of saflufenacil in the soil for almost all cultivars, however, Talismã, IAPAR 81 and Campeiro cultivars did not differ of the other treatment without herbicide (Figure 2 A). In the avaliation performed at 35 DAA, was not found any reduction in height after application of $14.7 \mathrm{~g}$ ha $^{-1}$ of saflufenacil in seven of the ten cultivars evaluated, 
demonstrating the ability of recovering from the effects of the herbicide. However, the Talismã was the only cultivar to suffer no significant reduction in plant height with the use of higher dose of saflufenacil, $29.4 \mathrm{~g} \mathrm{ha}^{-1}$ in both evaluations performed (Figures $2 \mathrm{~A}$ and $\mathrm{B}$ ), demonstrating greater tolerance among all genotypes.

The use of saflufenacil $\left(200 \mathrm{~g} \mathrm{ha}^{-1}\right)$ in preemergence (dose higher than used in the present experiment) resulted in $63-93 \%$ reduction in plant height of adzuki, cranberry, lime, snap and white beans, while reductions in pea and soybean heights were below $15 \%$ (Soltani et al. 2010). The selectivity of the main herbicides used in sugarcane crops, applied pre- or post-emergence to the dry bean cultivar Jalo Precoce was evaluated by Fernandes et al. (2011). The use of sulfentrazone ( $\left.600 \mathrm{~g} \mathrm{ha}^{-1}\right)$, herbicide with the same mechanism of action of saflufenacil, pre-emergence, resulted in $51 \%$ loss of the stand at 10 days after emergence (DAE) and 64\% loss of height at $25 \mathrm{DAE}$, compared to the check. When comparing eight bean cultivars, Hekmat et al. (2007) found no differences in reductions of plant height among cultivars by the use of sulfentrazone at $420 \mathrm{~g} \mathrm{ha}^{-1}$.

Comparing the final height of plants of cultivars sprayed with saflufenacil with the control, it can be seen in the figure 3A that the cultivars Vereda, Talismã, Tiziu e Corujinha stood out for higher heights, while the cultivar Radiante showed the lowest height. The cultivar Talismã was highlighted by the smaller reduction in final height with saflufenacil application totaling a reduction of 12 and $24 \%$, respectively, at doses of 14.7 and $29.4 \mathrm{~g} \mathrm{ha}^{-1}$. The cultivars Jalo Precoce and Estilo also presented smaller reductions in final height at $14.7 \mathrm{~g}$ saflufenacil, with 12.4 and $4.8 \%$ reduction, but these same cultivars totaled 100 and $68.9 \%$ reduction in the dose of $29.4 \mathrm{~g}$ saflufenacil. Cultivars Corujinha and Vereda showed the greatest loss of final height with the dose of $14.7 \mathrm{~g}$, compared with the control, with reductions of 37.4 and $26.5 \%$ respectively (Figure $3 \mathrm{~A}$ ).

Comparing doses of saflufenacil within each cultivar (Figrue $3 \mathrm{~A}$ ), it is possible to verify that at a dose of $14.7 \mathrm{~g} \mathrm{ha}^{-1}$, the final height of plant cultivars Esplendor, Jalo Precoce, Radiante, Tiziu Estilo, Vereda, IAPAR 81, Talismã and Campeiro showed no significant difference compared with the untreated control. This dose of saflufenacil did not affect negatively the height of the first pod (Figure $3 \mathrm{~B}$ ) of the same cultivars above except Tiziu. The dose of saflufenacil $29.4 \mathrm{~g} \mathrm{ha}^{-1}$, showed a negative influence on the variables final plant height (Figure $3 \mathrm{~A}$ ) and height of the first pod (Figure $3 \mathrm{~B}$ ), however, both the cultivars Radiante and Talismã did not differ from the treatment without herbicide, demonstrating greater tolerance among genotypes. A grater height of first pod insertion is extremely important, because it means reducing losses due to non-harvest of pods close to the ground when using mechanized harvesting of the beans.

The sensitivity of the cultivar Jalo Precoce to sulfentrazone (PROTOX inhibitor) was identified by Fernandes et al. (2011), who found that the use of $600 \mathrm{~g}$ ha $^{-1}$ pre-emergence reduced plant height at physiological maturity (60 DAE) in $59.61 \%$. They also found $100 \%$ reduction in the first pod height of bean plants compared with the control, because there were no living plants at harvest or by not forming pods in surviving plants (Fernandes et al., 2011).

The number of pods per plant varied among cultivars and doses. The cultivar Talismã had the lowest percentage of loss of pods by using saflufenacil, of 5.8 and $10.4 \%$, respectively, for doses of 14.7 and $29.4 \mathrm{~g} \mathrm{ha}^{-1}$. The cultivar Jalo Precoce showed the greatest loss of pods with the dose $29.4 \mathrm{~g} \mathrm{ha}^{-1}$, with a reduction of $100 \%$. Spraying $14.7 \mathrm{~g}$ saflufenacil did not result in significant difference among cultivars. The use of $29.4 \mathrm{~g} \mathrm{ha}^{-1} \mathrm{de}$ saflufenacil decrease number of pods per plant of the cultivars Esplendor, Jalo Precoce, Tiziu e Estilo, however didn't decrease significantly number of pods per plant of Corujinha, Radiante, Vereda, Iapar 81, Talismã and Campeiro (Figure 4 B).

As for the weight of 400 grains (Figure $4 \mathrm{~B}$ ) there was a wide variation among the controls, as this is an intrinsic characteristic of each bean cultivar. Jalo Precoce and Radiante were the cultivars with higher grain weight. Corujinha and Esplendor were the cultivars with lower grain weight. Spraying $14.7 \mathrm{~g}$ saflufenacil did not result in significant difference among weight of 400 grains of the cultivars (Figure 4B). The use of $29.4 \mathrm{~g} \mathrm{ha}^{-1}$ of saflufenacil decrease weight of 400 grains only to the cultivars Esplendor, Jalo Precoce, Tiziu e Estilo, evidencing high similarity with the variable number of pods per plant (Figures $4 \mathrm{~B}$ and $\mathrm{A}$ ). The Talismã cultivar showed the lowest loss 400 grain weight, only $13.6 \%$ compared with the control, using the highest dose of saflufenacil. The cultivar Jalo Precoce was extremely sensitive to the dose $29.4 \mathrm{~g} \mathrm{ha}^{-1}$, a reduction of $100 \%$ in relation to its control.

There wasn't significant variation in grain yield between the controls without applying saflufenacil (Figure 5). The cultivars Corujinha, Talismã and Campeiro stood out by higher grain yield with $3,412,3,285$ and $3,196 \mathrm{~kg}$ $\mathrm{ha}^{-1}$. Considering the dose of $14.7 \mathrm{~g} \mathrm{ha}^{-1}$, all cultivars had decreased yield, but the cultivar Talismã had the lowest loss of only $26.1 \%$. The cultivar Jalo Precoce exhibited the greatest reduction in yield for that dose of $61.4 \%$ compared 
with the control. As for the dose of $29.4 \mathrm{~g} \mathrm{ha}^{-1}$ there was high sensitivity of cultivars Corujinha, Esplendor, Jalo Precoce, Radiante, Tiziu, Estilo, Campeiro, Vereda, IAPAR 81 and Campeiro, with reductions of $98.2,98.7,100,93.0,98.6,98.4,92.7,65.7,65.4$ and $92.7 \%$ of yield compared with the control. The cultivar
Talismã was the only that showed no differences in grain yield between the doses of 14.7 and $29.4 \mathrm{~g} \mathrm{ha}^{-1}$ of saflufenacil, with a reduction by $36.9 \%$ yield with the use of the highest dose of saflufenacil, standing out for its lower sensitivity to the herbicide compared with other cultivars.
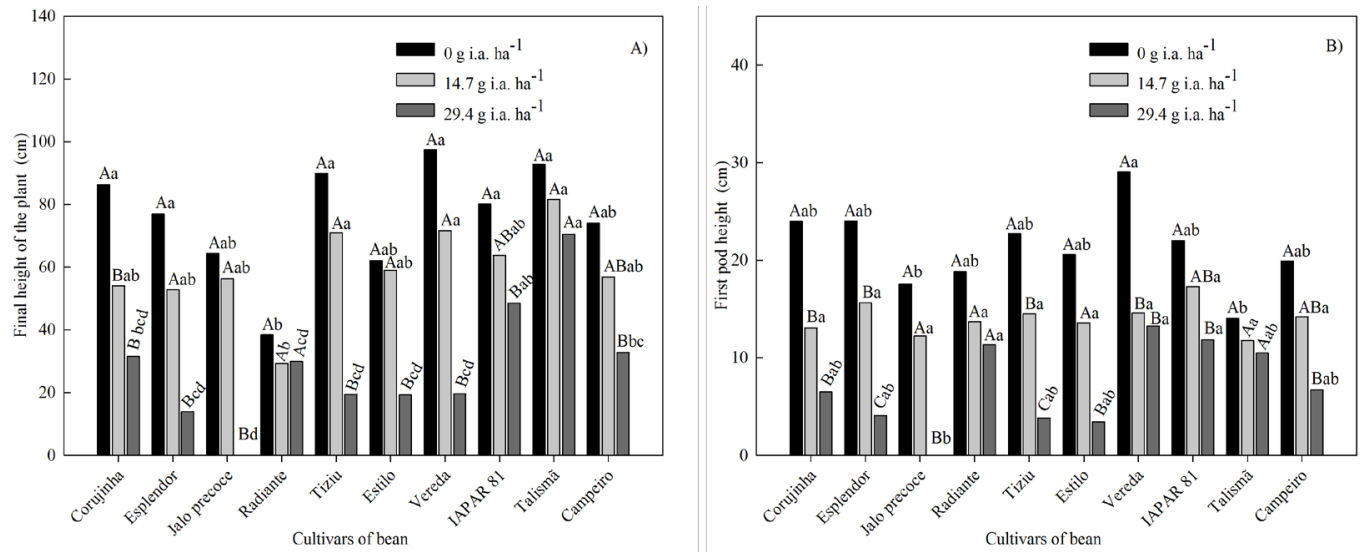

Figure 3 - Final height of the plant (A) first pod height (B) in ten bean cultivars at physiological maturity in the treatment without herbicide application and in response to two doses of saflufenacil - UTFPR, Pato Branco/2012. Means values followed by the same lower case indicate no difference between cultivars, within each dose, by the Tukey test $(\mathrm{P}<$ 0.05). ((Final height of the plant D.M.S=38.03; $\mathrm{CV}=24.8$ ) (First pod height D.M.S=10.9 $\mathrm{CV}=28.6)$ ). Means values followed by the same capital letter mean no difference between doses within each cultivar, using the Tukey test (P $<0.05)$. ((Final height of the plant D.M.S=27.7; $\mathrm{CV}=24.8)$ (First pod height D.M.S=7.9; $\mathrm{CV}=28.6)$ ).
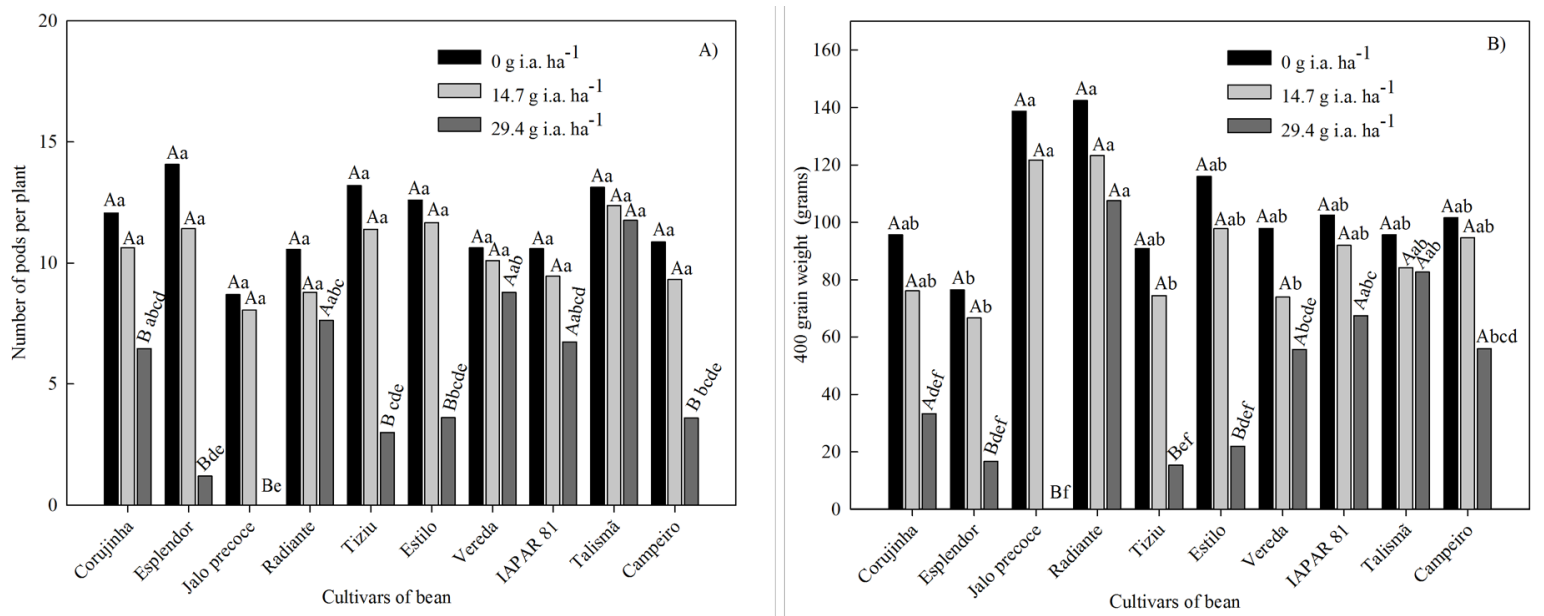

Figure 4 - Number of pods per plant (A) and 400 grain weight (B) of ten bean cultivars in response to saflufenacil doses - UTFPR, Pato Branco/2012. Means values followed by the same lower case indicate no difference between cultivars, within each dose, by the Tukey test $(\mathrm{P}<0.05)$ ((Number of pods per plant D.M.S=5.6; $\mathrm{CV}=22.9)(400$ grain weight D.M.S=53.8; $\mathrm{C}=22.4)$ ). Means values followed by the same capital letter mean no difference between doses within each cultivar, using the Tukey test $(\mathrm{P}<0.05)$ ((Number of pods per plant D.M.S=4.1; CV=22.9) (400 grain weight D.M.S=39.3; $\mathrm{C}=22.4)$ ). 


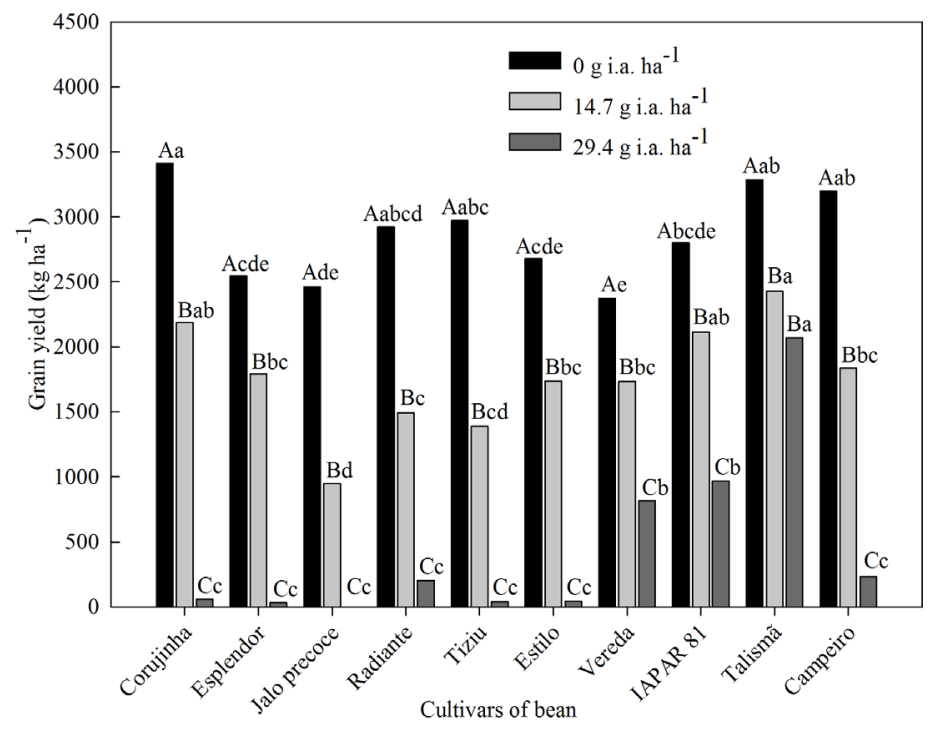

Figure 5 - Grain yield of ten bean cultivars in response to saflufenacil doses - UTFPR, Pato Branco/2012. Means values followed by the same lower case indicate no difference between cultivars, within each dose, by the Tukey test $(\mathrm{P}<$ 0.05) ((Number of pods per plant D.M.S $=489.5 ; \mathrm{CV}=10.7)$. Means values followed by the same capital letter mean no difference between doses within each cultivar, using the Tukey test $(\mathrm{P}<0.05)$ ( (Grain yield D.M.S=357.6; CV=10.7).

The sensitivity of the legumes to saflufenacil $\left(100 \mathrm{~g} \mathrm{ha}^{-1}\right)$ was investigated by Soltani et al. (2010) who found that grain yield of seven legumes was affected by the herbicide, with reductions ranging from 56 to $99 \%$ in adzuki, cranberry, lime, snap and white beans, but for soybean and peas the reduction was only $5 \%$. A study by Hekmat et al. (2007) examined the sensitivity of eight groups of commercial beans to sulfentrazone $\left(840 \mathrm{~g} \mathrm{ha}^{-1}\right)$, and detected a reduction in the yield of black, cranberry, white, and otebo beans of $47,44,26$ and $52 \%$, respectively. There was no reduction in yield for brown, kidney, pinto and yellow eye beans.

The differential tolerance to herbicides among cultivars has been the subject of study for several crop species (Barros et al., 2005, Fontana et al., 2007; Souza et al., 2009; Zera et al., 2011; Silva et al. 2011). It is known the differential selectivity of sulfentrazone to soybean cultivars (Swantek, Sneller; Oliver, 1998; Barros et al., 2005). The Brazilian company COODETEC released soybean cultivars with greater tolerance to sulfonylurea. This tolerance was obtained by mutagenesis followed by selection with the herbicide chlorsulfuron and isolation of the gene Als1, whose source is the genotype Williams 20 , characterizing this resistance as monogenic and semidominant (Sebastian; Chaleff, 1987).
The selectivity of PROTOX inhibiting herbicides to planted species can be explained by differential degradation of the herbicide, sensitivity variation among species to the toxic effects of singlet oxygen and the different sensitivity of the site of action. Metabolization is the most important mechanism of selectivity for PROTOX inhibiting herbicides (Merotto Jr.; Vidal, 2001). The metabolization of carfentrazoneethyl 24 hours after the application was 73, 46 and $39 \%$ in soybean, Ipomoea hederacea and Abutilon theophrasti, respectively (Dayan et al., 1997), but in soybeans were found toxic radicals at lethal levels to this culture, and hence it is speculated that in addition to metabolization, high levels of antioxidants and detoxifying enzymes are also responsible for selectivity in soybean. The selectivity can also be related to the interception, absorption and differential translocation between species. Variation in the efficiency of plants tolerant to PROTOX inhibiting herbicides in relation to the presence of compounds (dithiothreitol, betamercaptoethanol, ascorbic acid) that act on the inactivation of protoporphyrinogen IX were verified by Jacobs, Jacobs and Duke (1996), which indicated that the difference in susceptibility between plants may be related to the presence of these compounds in varying concentrations for each species. 
In the present study the bean cultivar BRS Talismã stood out by the high tolerance to soil saflufenacil considering all variables. However, even this cultivar suffered significant mortality of plants, represented by the loss of stand $(45 \%)$ reduction in plant growth and yield (39\%) with the use of the highest dose $29.4 \mathrm{~g} \mathrm{ha}^{-1}$ saflufenacil. Some of these effects could be corrected by management practices. Firstly, tolerant cultivars and appropriate doses could be combined with intervals between saflufenacil application and bean sowing to determine less injury to bean plants. Secondly, the increase in plant population would be recommendable in areas with use of saflufenacil, in which would be planted beans, capable of compensating for the loss of the stand. The rise in plant population of the crop would also result in an increase in the first pod height, which would result in lower losses in the harvesting process.

In addition to information to be used in management programs for bean cultivation, the discovery of more tolerant cultivars to saflufenacil points to the use of this trait in breeding programs, where this trait could be incorporated into strains and cultivars. There is also need in future studies to understand the mechanisms of tolerance to saflufenacil in bean cultivars with possibility to confirm or refute the hypotheses.

\section{CONCLUSIONS}

There was great variability in tolerance of bean cultivars to saflufenacil. Talismã cultivar showed higher tolerance to saflufenacil, demonstrating potential for use in breeding programs of this culture. Jalo Precoce cultivar presented greater sensitivity to the herbicide.

\section{ACKNOWLEDGEMENTS}

To CAPES, CNPq and UTFPR, for providing fellowships and financial support.

\section{REFERENCES}

BARBOSA, F. R.; GONZAGA, A. C. O. Informações técnicas para o cultivo do feijoeiro-comum na Região Central-Brasileira: 2012-2014. Informativo técnino. Embrapa Arroz e Feijão, Santo Antônio de Goiás, GO, 248 p., $1^{\text {a }}$ edição, 2012.

BARROS, A. C. et al. Tolerância de cultivares de soja aos herbicidas imazaquin, diclosulam e sulfentrazone, aplicados em solo de textura arenosa. Revista

Brasileira de Herbicidas. 4(1):1-8, 2005.
BORÉM, A.; CARNEIRO, J. E. S. A cultura. In: VIEIRA, C.; PAULA JÚNIOR, T. J.; BORÉM, A. (Ed.). Feijão. 2. ed. Viçosa: UFV, p.13-18, 2006.

DAYAN, E. D. et al. Selectivity and mode of action of carfentrazone-ethyl, a novel phenyl triazolinone herbicide. Pesticide Science. 57:65-73, 1997.

EMPRESA BRASILEIRA DE PESQUISA AGROPECUÁRIA - EMBRAPA. Centro Nacional de Pesquisa de Solos. Sistema Brasileiro de Classificação de Solos. 2.ed. Rio de Janeiro, 306p., 2006.

FERNANDES, C. P. C. et al. Tolerância do feijoeiro a herbicidas aplicados na cultura da cana-de-açúcar.

Revista Brasileira de Herbicidas. 10(2):121-133, 2011.

FERREIRA, F. A. et al. Manejo de plantas daninhas. In: VIEIRA, C.; JUNIOR, T. J. P.; BORÉM, A. Feijão. 2. ed. Viçosa: Universidade Federal de Viçosa. Cap.11, p.309-340, 2006.

FONTONA, L. C. et al. Tolerância de cultivares de arroz irrigado (Oryza sativa) ao herbicida nicosulfuron e à mistura formulada de imazethapyr + imazapic. Planta Daninha. 25(4):791-798, 2007.

GEIER, P. W.; STAHLMAN, P. W.; CHARVAT, L. D. Dose response of five broadleaf weeds to saflufenacil. Weed Technology. 23(2):313-316, 2009.

GROSSMANN, K. et al. Saflufenacil (Kixor $\left.{ }^{\mathrm{TM}}\right)$ : biokinetic properties and mechanism of selectivity of a new protoporphyrinogen IX oxidase inhibiting herbicide. Weed Science. 59(3):290-298, 2011.

HEKMAT, S. et al. Responses of dry beans (Phaseolus vulgaris L.) to sulfentrazone. Crop Protection. 26(4):525-529, 2007.

INOUE, M. H. et al. Eficácia de herbicidas aplicados em plantas adultas de Crotalaria spectabilis e Crotalaria ochroleuca. Revista Brasileira de Herbicidas. 11(2):148-158, 2012.

JACOBS, J. M.; JACOBS, N. J.; DUKE, S. O. Protoporphyrinogen destruction by plant extracts and correlation with tolerance to protoporphyrinogen oxidase-inhibiting herbicides. Pesticide Biochemistry and Physiology. 55:77-83, 1996. 
KNEZEVIC, S. Z. et al. Tolerance of winter wheat (Triticum aestivum L.) to pre-emergence and postemergence application of saflufenacil. Crop Protection. 29(2):148-152, 2010.

KOZLOWSKI, L. A. et al. Critical period of weed interference in the culture of the common bean in notillage. Planta Daninha. 20(2):213-220, 2002.

MACHADO, A. A.; CONCEIÇÃO, A. R. WinStat - sistema de análise estatística para Windows. Versão Beta. Pelotas: Universidade Federal de Pelotas. (Software), 2005.

MARTINS, D.; et al. Manejo químico de espécies de trapoeraba com aplicação isolada e em mistura de diferentes herbicidas. Revista Caatinga. 25(2):21-28, 2012.

MEROTTO JR., A.; VIDAL, R. A. Herbicidas inibidores de Protox. In: VIDAL, R. A.; MEROTTO Jr., A. Herbicidologia, Porto Alegre: Evangraf, p.69-86, 2001.

MONQUERO, P. A.; DALLA COSTA, V.;

KROLIKOWSKI, V. Saflufenacil no controle de Luffa aegyptiana, Merremia cissoides, Mucuna aterrima e Ricinus communis. Revista Brasileira de Herbicidas. 10(3):176-00, 2011

SALGADO, T. P. et al. Weed interference in carioca bean. Planta Daninha. 25(3):443-448, 2007

SEBASTIAN, S. A.; CHALEFF, R. S. Soybean mutants with increased tolerance for sulfonylurea herbicides. Crop Science. 27(5):948-952, 1987.
SIKKEMA, P. H.; SHROPSHIRE, C.; SOLTANI, N. Tolerance of spring barley (Hordeum vulgare L.), oats (Avena sativa L.) and wheat (Triticum aestivum L.) to saflufenacil. Crop Protection. 27(12):1495-1497, 2008.

SILVA, D. V. et al. Tolerância de cultivares de mandioca aos herbicidas fomesafen e fluazifop-p-butil. Revista Brasileira de Herbicidas. 10(3):219-231, 2011.

SOLTANI, N.; BOWLEY, S.; SIKKEMA, P. H. Responses of dry beans to flumioxazin. Weed Technology. 19(2):351-358, 2005.

SOLTANI, N, et al. Response of corn to preemergence and postemergence applications of saflufenacil. Weed Technology. 23(3):331-334, 2009.

SOLTANI, N.; SHROPSHIRE, C.; SIKKEMA, P. H. Sensitivity of leguminous crops to saflufenacil. Weed Technology. 24(2):143-146, 2010.

SOUZA, J. R. et al. Tolerância de cultivares de canade-açúcar a herbicidas aplicados em pós-emergência. Bragantia. 68(4):941-951, 2009.

SWANTEK, J. M.; SNELLER, C. H.; OLIVER, L. R. Evaluation of soybean injury from sulfentrazone and inheritance of tolerance. Weed Science. 46:271-277, 1998.

VELINI, E. D. et al. Avaliação da seletividade da mistura de oxyfluorfen e ametryne, aplicada em pré ou pós-emergência, a dez variedades de cana-deaçúcar (cana-planta). Planta Daninha. 18(1):123-134, 2000.

ZERA, F. S. et al. Tolerância de diferentes cultivares de cana-de-açúcar (Saccharum spp.) A herbicidas. Planta daninha. 29(3):591-599, 2011. 